\title{
Sistem Deteksi Kebocoran Gas Berbasis Arduino Menggunakan Gas Detector
}

\author{
Evi Rahmawati ${ }^{\mathrm{a}, 1, *}$, Fariyatul Aeni ${ }^{\mathrm{a}, 2}$ \\ ${ }^{a}$ Universitas Amikom Yogyakarta \\ ${ }^{1}$ evi.rahmawati@students.amikom.ac.id, ${ }^{2}$ fariyatul.aeni@students.amikom.ac.id \\ * Penulis Korespondensi
}

\section{ABSTRAK}

Seperti yang kita ketahui kebakaran merupakan hal yang sangat merugikan, terutama bagi manusia. Selain merugikan, kebakaran juga akan berdampak negatif, seperti hilangnya harta benda bahkan nyawa. Banyak faktor penyebab kebakaran, darimulai hubungan pendek arus listrik sampai kebocoran gas. Maka dari itu kita harus berusaha untuk meminimalisir adanya kejadian yang tidak diinginkan. Setelah kita melihat banyaknya kebakaran baik di internet, televisi, koran dsb maka kita berinovasi untuk membuat sebuah sistem deteksi kebakaran berbasis arduino uno menggunakan sensor gas. Tujuan dari adanya pembuatan sistem deteksi kebakaran yaitu untuk mengantisipasi adanya kebakaran, dengan begitu kita dapat meminimalisir dampak -dampak yang ditimbulkan oleh kebakaran, sehingga ketika adanya sistem pendeteksi tersebut tidak akanterjadi kebakaran dan menimbulkan banyak resiko.

Kata Kunci : kebakaran, sensor gas, dan sistem

\section{Pendahuluan}

Kebakaran sering terjadi di Indonesia, dampak dari hal tersebut tidak sedikit harta benda bahkan nyawa yang menjadi korban. Banyak penyebab terjadinya kebakaran yaitu karena hubungan pendek arus listrik, bocornya tabung gas LPG, kecerobohan manusia dll. Api kebakaran sangat mudah menyebar, jika tidak segera di padamkan, api akan membakar habis ruangan dan menyebabkan kerugian. Dari pandangan itu dapat disimpulkan adanya masalah yang harus dipecahakan.

Dengan berkembangan teknologi yang ada sampai saat ini tujuan kami untuk meminimalisir keterlambatan penanganan kebakaran, kami membuat sebuah sistem yang bisa mendeteksi kebocoran gas LPG.

Beberapa tujuan dibuatnya sistem pendeteksi kebocoran :

1. Mengetahui cara mensimulasikan alat pendeteksi kebocoran

2. Dapat meminimalisir adanya kejadian kebakaran yang beresiko tinggi

3. Mengetahui adanya kebocoran gas ketika gas detector tersebut mendeteksi adanya gas

4. Menjaga keamanan ruangan agar tidak timbul adanya kebakaran

\section{Metode Penelitian}

Penelitian dilakukan dengan menggunakan simulasi model perancangan. Mulai dari pengamatan, pengumpulan data, menganalisa data, memecahkan suatu masalah, mendesain suatu produk, dan menguji simulasi produk.

1. Melakukan pengamatan terhadap suatu objek yang kemudian menghasilkan suatu informasi, dan menjadi sebuah hipotesis.

2. Melakukan pengumpulan data untuk menghasilkan bahan yang kemudian digunakan untuk mengembangkan hasil dan menguatkan data dari hipotesis sebelumnya.

3. Menganalisa seluruh data dengan berbagai sumber yang tersedia, kemudian memecahkan suatu permasalahan menggunakan data yang telah dianalisa sebelumnya.

4. Mendesain rancangan produk dengan menggunakan proteus dan arduino uno. 
Cara pembuatan desain rancangan produk yaitu :

1. Melengkapi semua komponen yang akan digunakan seperti :

a. Arduino Uno adalah papan mikrokontroler berdasarkan ATmega328 (lembar data) dengan memiliki 14 digital pin input / output.

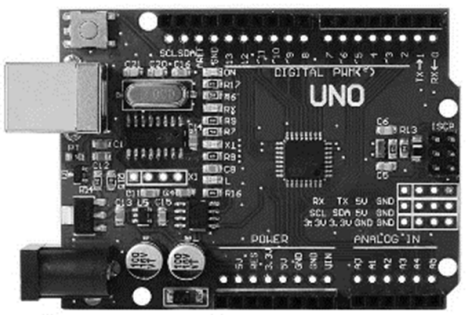

Gambar 1. Arduino Uno

b. LED adalah perangkat elektronik yang memancarkan cahaya ketika arus listrik dilewatinya.

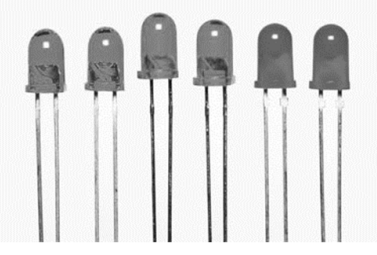

Gambar 2. Led Lamp

c. Logicstate benar atau salah, dari sinyal biner yang diberikan. Sinyal biner adalah sinyal digital yang hanya memiliki dua nilai valid.

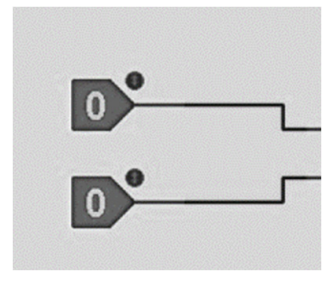

Gambar 3. LM35

d. MQ - 2 Gas Sensor digunakan dalam peralatan deteksi kebocoran gas di pasar konsumen dan industri

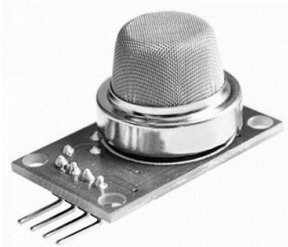

Gambar 4. MQ-2 Gas Sensor 
2. Merangkai komponen yang sudah tersedia, seperti pada gambar berikut :

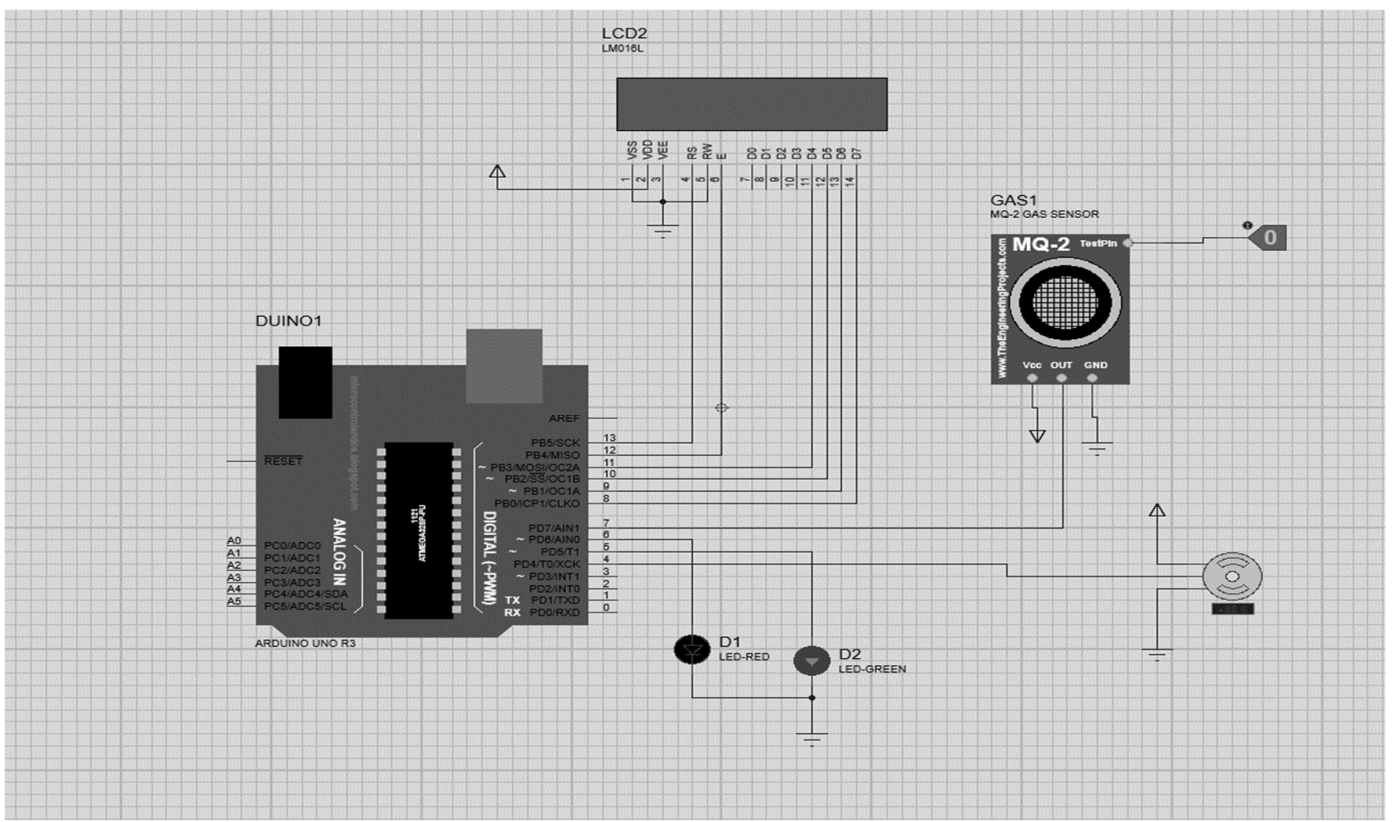

Gambar 5. Rangkain simulasi deteksi kebakaran

3. Setelah selesai menyusun rangkaian di proteus anda simpan atau compile program yang sudah di buat di arduino unoini menjadi file HEX dan jika anda tidak menggunakan Proteus, upload sketch langsung ke board Arduino.

Langkah terakhir adalah melakukan pengujian produk dengan metode simulasi dari proteus, dengan melakukan pengujian berulang - ulang sampai diperoleh produk yang memenuhi syarat.

\section{Hasil dan Pembahasan}

Dari banyaknya kejadian kebakaran yang terjadi di Indonesia, dapat kita simpulkan bahwasanya perlu adanya pengamanan atau kita harus dapat meminimalisir kejadian - kejadian yang tidak diinginkan, maka dari itu kita merancang sebuah sistem deteksi kebakaran dengan sensor gas. Sistem deteksi kebakaran dengan sensor api dan gas ini dapat dikembangkan dengan teknologi dan informasi yang semakin canggih, seperti halnya kita dapat menggunakan alat proteus dan Arduino uno sebagai alarm atau pendeteksi adanya kebakaran disuatu ruangan tersebut, dengan begitu keamanan dan keselamatan akan lebih terjaga.

Sistem deteksi akan bekerja ketika dalam suatau ruangan tersebut mengeluarkan gas dan api. Maka dengan otomatis gas dan api akan dideteksi dan ditangkap oleh MQ-2 Gas Sensor dan flame sensor. Kemudian komponen MQ-2 Gas Sensor dan flame sensor akan memberikan informasi kepada Chip Arduino uno bahwasanya ruangan tersebut terjadi kebakaran dari adanya percikan api dan adanya gas. Setelah Chip Arduino uno mengetahui adanya gas dan api maka secara otomatis kepada speaker yang kemudian alarm akan mengeluarkan bunyi dengan pertanda bahwasanya di ruangan terjadi kebakaran. Tetapi, ketika dalam suatu ruangan tersebut hanya terdapat gas yang kemudian disensor dan diterima oleh MQ-2 Gas Sensor saja yang kemudian disalurkan kepada Arduino uno system tersebut tidak mengeluarkan bunyi karna tidak adanya api yang terdeteksi oleh flame sensor. Begitu juga dengan sebaliknya, ketika hanya api saja yang diterima oleh flame sensor yang kemudian disalurkan kepada Arduino uno tidak mengeluarkan bunyi alarm, karena tidak adanya gas. 


\section{Kesimpulan}

Adanya sistem pendeteksi kebakaran dengan menggunakana sensor gas dan api ini sangatlah membantu keamanan, keselamatan, bahkan dapat meminimalisir kejadian kebakaran.

Dari sistem pendeteksi kebakaran sendiri memiliki kesimpulan bahwasanya :

1. Sistem pendeteksi kebakaran akan memberikan informasi berupa bunyi atau alarm dari speaker yang menandakan adanya kebakaran dalam suatu ruangan dengan terdeteksinya gas dan api.

2. Arduino uno dapat bekerja sampai dengan memberikan perintah kepada speaker ketika adanya gas yang dideteksi oleh MQ-2 Gas Sensor dan Api yang dideteksi oleh Flame Sensor.

\section{Rekomendasi}

Dengan semakin berkembangnya teknologi dan informasi dapat kita lakukan apa saja yang membuat kita menjadi aman dan menjaga keselamatan kita. Karena pada dasarnya teknologi yang semakin canggih ini adalah cara memudahkan kita untuk mengembangkan potensi dan selalu berinovatif dalam sebuah karya maupun produk. Indonesia sendiri sering terjadi kebakaran baik didalam maupun diluar ruangan. Hal yang sering terjadi yaitu akibat hubungan arus pendek listrik maupun kelalaian manusia sendiri, dengan adanya Sistem pendeteksi kebakaran dengan berbasis gas dan api ini sangat membantu kita dalam meminimalisir terjadinya kebakaran. Karena tidak sedikit harta benda bahkan nyawa yang menjadi korban akibat adanya kejadian kebakaran, maka dapat kita gunakan dan kembangkan sistem pendeteksi kebakaran tersebut.

\section{Ucapan Terima Kasih}

Kami sangat menyadari bahwa jurnal ini masih banyak kesalahan dan jauh dari kata sempurna. Kami memohon kritik dan saran yang membangun sehingga kami dapat lebih mengembangkan dan memperbaiki jurnal ini sehingga bias menjadi yang lebih lagi. Kami juga berterima kasih kepada pihak - pihak yang telah membantu dalam menyelesaikan jurnal ini sehingga jurnal ini dapat terselesaikan. Kami juga berterimakasih kepada :

1. Bp. Ferry Wahyu Wibowo selaku dosen pengampu mata kuliah komunikasi data.

2. Para asisten dosen yang telah menemani dan menuntun kami dalam berjalannya praktikum komunikasi data.

3. Dan juga teman - teman yang telah mensuport dan membantu sehingga pembuatan jurnal ini berjalan dengan lancar.

\section{Referensi}

[1] Wardhana, Lingga.Belajar Sendiri Mikrokontroler AVR Seri ATMega8535 Simulasi, Hardware, dan Aplikasi. Penerbit Andi. Yogyakarta. 2006

[2] Heryanto ST, M. Ary. 2008 .Pemograman Bahasa C Untuk Mikrokontroler ATMEGA 8535. Andi. Yogyakarta

[3] C. P. Mulya and N. Nurkhamid, "Prototype Monitoring Kebakaran Hutan Via Website Berbasis Arduino," E-JPTE (Jurnal Elektron. Pendidik. Tek. Elektron., vol. 4, no. 7, pp. 9-18, 2015.

[4] K Sen, J Sarkar, S Saha, A Roy, D Dey, and S Baitalik, "Automated Fire Detection and Controlling System,” Int. Adv. Res. J. Sci. Eng. Technol., vol. 2, no. 5, pp. 34-37, 2015.

[5] Muhammad Taufan, Sistem Pemadam Kebakaran Pada Gedung. Bandung. 2000.

[6] Song, AO, Digital-output relative humidity \& temperature sensor/ module, DFRObot dan Didkson Kho, Cara Kerja Buzzer, 2015 
[7] Hobby Component, Units 19A \& B, Clocktower Business Centre, Works Road, Chesterfield, Hollingwood. MQ - 2 Gas Sensor . (https://hobbycomponents.com/sensors/146-gas-sensormq2)

[8] Electronic Future, Flame Sensore Module, Cairo (https://store.futelectronics.com/products/flame-sensor-module)

$[9$

Collins English Dictionary, Sounder. Westerhill Road,
(https://www.collinsdictionary.com/dictionary/english/sounder) 